\title{
Sphingobacterium shayense sp. nov., isolated from forest soil
}

Correspondence

Erkin Rahman

erkin1106@yahoo.com

\author{
Xiang He, ${ }^{1}$ Ting Xiao, ${ }^{1}$ Haiju Kuang, ${ }^{1}$ Xiaojun Lan, ${ }^{1}$ Maripat Tudahong, ${ }^{1}$ \\ Ghenijan Osman, ${ }^{1}$ Chengxiang Fang ${ }^{2}$ and Erkin Rahman ${ }^{1}$
}

${ }^{1}$ College of Life Science and Technology of Xinjiang University, Urumqi, Xinjiang 830046, PR China
${ }^{2}$ College of Life Sciences, Wuhan University, Wuhan 430072, PR China

\begin{abstract}
A Gram-staining-negative, yellow-coloured, strictly aerobic, non-spore-forming, rod-shaped bacterium, designated $\mathrm{HS} 39^{\top}$, isolated from a soil sample collected from a natural Populus euphratica forest in Xinjiang, China, was characterized using a polyphasic approach. The isolate grew optimally at $30-37{ }^{\circ} \mathrm{C}$, at $\mathrm{pH} 6.5-8.0$ and with $0-3 \% \mathrm{NaCl}$. Analysis of the 16S rRNA gene sequence of strain $\mathrm{HS} 9^{\top}$ revealed that it is a member of the genus Sphingobacterium. Sphingobacterium mizutaii ATCC $33299^{\top}$ was the nearest relative $(94.0 \% 16 \mathrm{~S}$ rRNA gene sequence similarity). The $\mathrm{G}+\mathrm{C}$ content of the genomic DNA was $40.2 \mathrm{~mol} \%$. The major fatty acids were iso- $\mathrm{C}_{15: 0}$, iso- $\mathrm{C}_{17: 0} 3-\mathrm{OH}$ and summed feature 3 (comprising $\mathrm{C}_{16: 1} \omega 6 \mathrm{c}$ and/or $\left.\mathrm{C}_{16: 1} \omega 7 \mathrm{c}\right)$. The predominant isoprenoid quinone was MK-7. On the basis of phenotypic properties and phylogenetic inference, strain $\mathrm{HS} 9^{\top}$ represents a novel species of the genus Sphingobacterium, for which the name Sphingobacterium shayense sp. nov. is proposed. The type strain is $\mathrm{HS}^{\top} 9^{\top}\left(=\mathrm{CCTCC}^{\mathrm{AB}} 209006^{\top}=\mathrm{NRRL} \mathrm{B}^{-59203^{\top}}\right)$.
\end{abstract}

The genus Sphingobacterium was proposed originally by Yabuuchi et al. (1983), who distinguished members of the new genus from Flavobacterium strains by the presence of high concentrations of sphingophospholipids. At the time of writing, the genus comprised 12 species: Sphingobacterium spiritivorum (the type species), S. anhuiense, S. antarcticum, S. canadense, S. composti, S. daejeonense, S. faecium, S. kitahiroshimense, S. mizutaii, S. multivorum, S. siyangense and S. thalpophilum (Wei et al., 2008; Shivaji et al., 1992; Mehnaz et al., 2007; Ten et al., 2006; Kim et al., 2006; Takeuchi \& Yokota, 1992; Matsuyama et al., 2008; Yabuuchi et al., 1983; Liu et al., 2008). The name Sphingobacterium composti has been proposed for two different strains (Ten et al., 2006; Yoo et al., 2007). As the name Sphingobacterium composti Yoo et al. 2007 is a later homonym of Sphingobacterium composti Ten et al. 2007 (http://www. bacterio.cict.fr/s/sphingobacterium.html), the type strain of Sphingobacterium composti Yoo et al. 2007 was not considered in this study. Sphingobacterium is the type genus of the family Sphingobacteriaceae (Steyn et al., 1998) in the phylum Bacteroidetes.

In a series of studies, we attempted to isolate microorganisms from soil samples in order to investigate the community structure using a culture-dependent method. In this study, strain $\mathrm{HS} 39^{\mathrm{T}}$, isolated from a soil sample collected from the largest natural Populus euphratica forest

The GenBank/EMBL/DDBJ accession number for the 16S rRNA gene sequence of strain $\mathrm{HS}^{\top}{ }^{\top}$ is $\mathrm{FJ} 816788$. in Xinjiang, China, located in the north-west Tarim basin $\left(40^{\circ} 56^{\prime} 35^{\prime \prime} \mathrm{N} 83^{\circ} 22^{\prime} 18^{\prime \prime} \mathrm{E}\right)$, was characterized by means of a polyphasic approach to determine its taxonomic position. This approach included phylogenetic analyses based on 16S rRNA gene sequences and determination of chemotaxonomic and other phenotypic properties.

Strain $\mathrm{HS}_{3} 9^{\mathrm{T}}$ was isolated using the dilution-plating technique on Luria-Bertani (LB) agar (5 g yeast extract, $10 \mathrm{~g}$ peptone, $10 \mathrm{~g} \mathrm{NaCl}, 1000 \mathrm{ml}$ distilled water, $\mathrm{pH} 7.0$ 8.0) at $30{ }^{\circ} \mathrm{C}$. The $16 \mathrm{~S}$ rRNA gene of strain $\mathrm{HS}^{2} 9^{\mathrm{T}}$ was amplified by PCR with primers 27F (5'-GAGTTTGATCCTGGCTCAG-3') and 1527R (5'-AGAAAGGAGGTGATCCAGCC- $\left.3^{\prime}\right)$. The PCR product obtained was sequenced by the dideoxynucleotide chain-termination method, using a BigDye Terminator version 3.0 cycle sequencing ready kit (Applied Biosystems) and a DNA sequencer (ABI Prism 3100). The 16S rRNA gene sequence of strain $\mathrm{HS} 9^{\mathrm{T}}$ was aligned with relevant sequences retrieved from GenBank using the CLUSTAL W program contained in the MEGA4 package. Phylogenetic trees were constructed by using the neighbour-joining (Saitou \& Nei, 1987) and maximum-parsimony (Fitch, 1971) methods, with bootstrap values based on 1000 replications (Felsenstein, 1985). Evolutionary distances were calculated using Kimura's two-parameter model (Kimura, 1980, 1983). For phylogenetic analyses, the 16S rRNA gene sequences of related type strains were obtained from the EzTaxon server (http://www.eztaxon.org; Chun et al., 2007). 
Neighbour-joining phylogenetic analysis based on comparison of $1440 \mathrm{bp}$ of the 16S rRNA gene sequence showed that strain $\mathrm{HS}_{3} 9^{\mathrm{T}}$ formed a coherent cluster with members of the genus Sphingobacterium in the phylum Bacteroidetes (Fig. 1). The maximum-parsimony tree showed essentially the same topology (not shown). Comparative 16S rRNA gene sequence analyses showed that strain $\mathrm{HS}_{3} 9^{\mathrm{T}}$ was closely related to S. mizutaii ATCC $33299^{\mathrm{T}}$, S. daejeonense TR6-04 ${ }^{\mathrm{T}}$ and $S$. composti $\mathrm{T} 5-12^{\mathrm{T}}$, with sequence similarities of $94.0,93.5$ and $93.1 \%$, respectively. $16 \mathrm{~S}$ rRNA gene sequence similarities to other members of the genus Sphingobacterium were lower than $93.1 \%$.

Strain $\mathrm{HS} 39^{\mathrm{T}}$ was cultivated routinely on LB agar or in LB broth at the same temperature for morphological, physiological and biochemical investigations. S. mizutaii ATCC $33299^{\mathrm{T}}$, S. composti KCTC $12578^{\mathrm{T}}$ and S. daejeonense KCTC $12579^{\mathrm{T}}$ were grown under the same conditions and used as reference strains in all physiological and biochemical tests. Cell morphology was observed using a scanning electron microscope and cell motility was studied on LB swarming agar $(0.3 \%$ agar, w/v). Gram staining, catalase and oxidase activities and hydrolysis of starch, casein, Tweens 20 and 80 and CM-cellulose were investigated as described by Smibert \& Krieg (1994). Additional physiological and biochemical tests were performed by using the API 20E, API $50 \mathrm{CH}$, and API ID 32 GN kits (bioMérieux). Enzyme activities were analysed using the API ZYM kit (bioMérieux) according to the manufacturer's instructions. Growth was assessed at 4, 10, 20, 25, 28, 30, 37, 40, 42, 45 and $50{ }^{\circ} \mathrm{C}$, at $\mathrm{pH} 5-11$ (at $0.5 \mathrm{pH}$ unit intervals) and with $0,1,2,3,4,5,6$ and $7 \% \mathrm{NaCl}(\mathrm{w} / \mathrm{v})$. Sensitivity to antibiotics was determined with the routine disc-diffusion $(8 \mathrm{~mm}$ diameter; Sanofi Pasteur) plate method. The following antibiotics were tested: lincomycin $(2 \mu \mathrm{g})$, ampicillin $(10 \mu \mathrm{g})$, neomycin $(30 \mu \mathrm{g})$, streptomycin $(10 \mu \mathrm{g})$, tetracycline $(30 \mu \mathrm{g})$, polymyxin B (300 IU), carbenicillin $(100 \mu \mathrm{g})$, gentamicin $(10 \mu \mathrm{g})$, kanamycin $(30 \mu \mathrm{g})$, doxycycline $(30 \mu \mathrm{g})$, chloramphenicol $(30 \mu \mathrm{g})$, nalidixic acid $(30 \mu \mathrm{g})$, rifampicin $(5 \mu \mathrm{g})$, vancomycin $(30 \mu \mathrm{g})$, erythromycin $(15 \mu \mathrm{g})$ and penicillin $\mathrm{G}(10 \mathrm{IU})$.
Strain $\mathrm{HS} 9^{\mathrm{T}}$ formed circular, smooth, yellow colonies after 2 days of incubation. Cells were short rods, 1.0$1.5 \mu \mathrm{m}$ long and $0.6-0.8 \mu \mathrm{m}$ in diameter, and were nonmotile. Other phenotypic properties of strain $\mathrm{HS}_{3} 9^{\mathrm{T}}$ are given in the species description and in Table 1.

For quantitative analysis of fatty acids, strain $\mathrm{HS} 39^{\mathrm{T}}, S$. mizutaii ATCC $33299^{\mathrm{T}}$, S. composti KCTC $12578^{\mathrm{T}}$ and $S$. daejeonense KCTC $12579^{\mathrm{T}}$ were cultivated on LB agar at $30{ }^{\circ} \mathrm{C}$ for $48 \mathrm{~h}$. Preparation and analysis of fatty acid methyl esters were conducted according to the standard protocol of the MIDI Microbial Identification System (Microbial ID). Isoprenoid quinones of strain $\mathrm{HS}^{\mathrm{T}} \mathrm{T}^{\mathrm{T}}$ were extracted according to the method of Collins et al. (1977) and analysed using reversed-phase HPLC (UltiMate 3000; Dionex) as described by Xie \& Yokota (2003). Genomic DNA of strain HS39 ${ }^{\mathrm{T}}$, S. mizutaii ATCC $33299^{\mathrm{T}}$, S. composti KCTC $12578^{\mathrm{T}}$ and S. daejeonense KCTC $12579^{\mathrm{T}}$ was prepared by the method of Wilson (1987) and the purity was checked spectrophotometrically. The DNA G+C contents of the four strains were determined by reversedphase HPLC using the method of Mesbah et al. (1989).

Strain HS39 $9^{\mathrm{T}}$ contained iso- $\mathrm{C}_{15: 0}(28.6 \%)$, iso- $\mathrm{C}_{17: 0} 3-\mathrm{OH}$ $(13.5 \%)$ and summed feature 3 (comprising $C_{16: 1} \omega 6 c$ and/ or $\left.\mathrm{C}_{16: 1} \omega 7 c ; 37.0 \%\right)$ as the major fatty acids. The fatty acid profiles of strain $\mathrm{HS}_{3} 9^{\mathrm{T}}$ and of the three reference strains were similar, although there were some differences in the proportions of some components (Table 2). The predominant isoprenoid quinone of strain $\mathrm{HS}_{3} 9^{\mathrm{T}}$ was MK-7, in line with all members of the family Sphingobacteriaceae, and its DNA G+C content was $40.2 \mathrm{~mol} \%$, within the range of values reported for Sphingobacterium species.

The overall phenotypic properties of strain $\mathrm{HS}_{3} 9^{\mathrm{T}}$ were consistent with its assignment to the genus Sphingobacterium. However, the combination of biochemical characteristics, differences in the fatty acid composition and phylogenetic inference distinguished strain $\mathrm{HS} 39^{\mathrm{T}}$ from all described Sphingobacterium species. Hence, it is proposed that it represents a novel species in the genus Sphingobacterium, with the name Sphingobacterium shayense sp. nov.

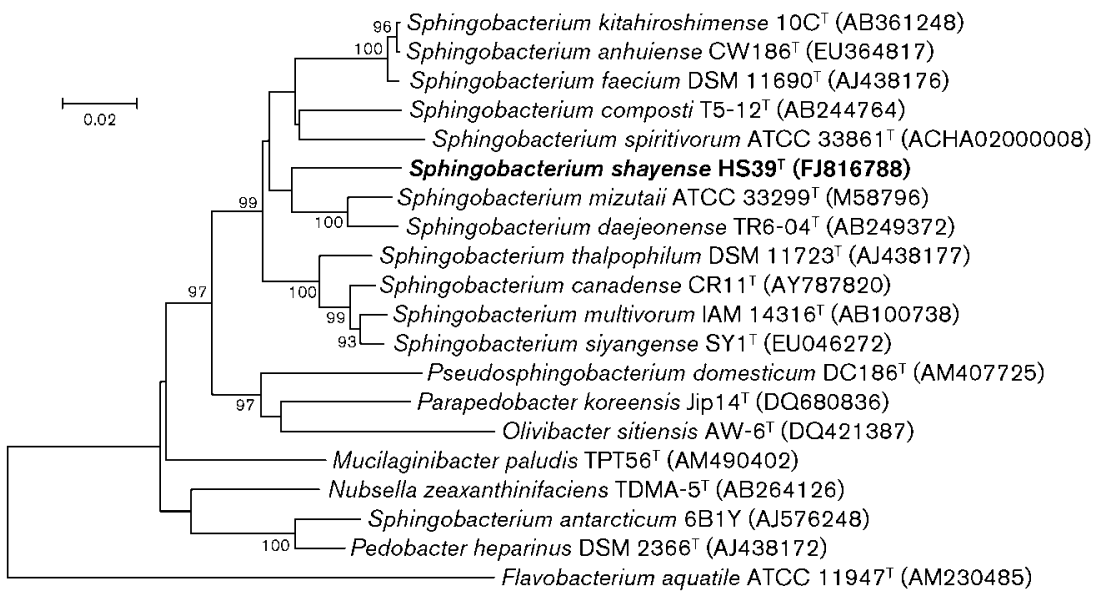

Fig. 1. Neighbour-joining phylogenetic tree based on 16S rRNA gene sequences showing the relationship of strain $\mathrm{HS}_{3}{ }^{\top}$ and representative members of the family Sphingobacteriaceae. Flavobacterium aquatile ATCC $11947^{\top}$ was used as an outgroup. Bootstrap values (expressed as percentages of 1000 replications) $>70 \%$ are shown at branching points. Bar, 0.02 substitutions per nucleotide position. 
Table 1. Differential characteristics of strain $\mathrm{HS} 9^{\top}$ and related members of the genus Sphingobacterium

Strains: 1, Sphingobacterium shayense sp. nov. $\mathrm{HS}^{\mathrm{T}}{ }^{\mathrm{T}}$; 2, S. mizutaii ATCC $33299^{\mathrm{T}} ; 3$, S. composti KCTC $12578^{\mathrm{T}}$; 4, S. daejeonense KCTC $12579^{\mathrm{T}}$. All data are from this study, including DNA G + C contents (means \pm SD from three determinations). All strains were positive for catalase and oxidase activities, assimilation of D-glucose, $\mathrm{N}$ acetylglucosamine, sucrose, maltose and salicin, acid production from glucose, melibiose and amygdalin and hydrolysis of Tween 20. All strains were negative for Gram staining, sporulation, $\mathrm{H}_{2} \mathrm{~S}$ and indole production, hydrolysis of casein and CM-cellulose, assimilation of D-ribose, inositol, glycogen, L-fucose, itaconic acid, acetate, sodium malonate, lactic acid, 3-hydroxybenzoic acid, L-serine, capric acid and 4-hydroxybenzoic acid and acid production from D-mannitol, inositol and D-sorbitol. +, Positive; -, negative; w, weakly positive.

\begin{tabular}{|c|c|c|c|c|}
\hline Characteristic & 1 & 2 & 3 & 4 \\
\hline $\begin{array}{l}\text { Temperature range for growth } \\
\left({ }^{\circ} \mathrm{C}\right)\end{array}$ & $10-40$ & $10-40$ & $10-42$ & $10-42$ \\
\hline $\mathrm{pH}$ range for growth & $5.5-9.0$ & $5.0-9.0$ & $6.5-9.0$ & $5.5-9.0$ \\
\hline Voges-Proskauer test & - & + & + & + \\
\hline \multicolumn{5}{|l|}{ Hydrolysis of: } \\
\hline Starch & + & + & - & - \\
\hline Tween 80 & + & + & + & - \\
\hline \multicolumn{5}{|l|}{ Assimilation of: } \\
\hline L-Rhamnose & + & - & - & - \\
\hline L-Arabitol & + & - & - & - \\
\hline L-Histidine & + & - & - & - \\
\hline D-Sorbitol & - & + & + & - \\
\hline Suberic acid & - & - & - & + \\
\hline L-Proline & - & - & - & + \\
\hline \multicolumn{5}{|l|}{ Acid production from: } \\
\hline Sucrose & + & + & - & - \\
\hline D-Galactose & + & - & + & + \\
\hline D-Fructose & - & - & - & + \\
\hline Melezitose & + & - & $\mathrm{w}$ & - \\
\hline Raffinose & + & - & - & - \\
\hline L-Fucose & W & + & + & - \\
\hline DNA G $+\mathrm{C}$ content $(\mathrm{mol} \%)$ & $40.2 \pm 0.1$ & $39.9 \pm 0.3$ & $35.4 \pm 0.1$ & $37.5 \pm 0.1$ \\
\hline
\end{tabular}

\section{Description of Sphingobacterium shayense sp. nov.}

Sphingobacterium shayense (sha.yen'se. N.L. neut. adj. shayense pertaining to Shaya county in Xinjiang Uyghur autonomous region of China, where the type strain was isolated).

Cells are Gram-staining-negative, non-motile, non-sporeforming, strictly aerobic rods, $1.0-1.5 \mu \mathrm{m}$ long and 0.6$0.8 \mu \mathrm{m}$ in diameter. After 2 days of incubation on LB agar, colonies are 1.0-2.0 $\mathrm{mm}$ in diameter, yellow, convex, circular and smooth with entire margins. Growth occurs between 10 and $40{ }^{\circ} \mathrm{C}$; optimum temperature for growth is $30-37{ }^{\circ} \mathrm{C}$. The $\mathrm{pH}$ range for growth is 5.5-9.0, with an optimum between $\mathrm{pH} 6.5$ and 8.0. Growth occurs in the presence of 0 $5 \%(\mathrm{w} / \mathrm{v}) \mathrm{NaCl}$; optimum concentration for growth is $0-3 \%$. $\mathrm{H}_{2} \mathrm{~S}$ and indole are not produced. Nitrate is not reduced. The Voges-Proskauer test is negative. Catalase, oxidase, alkaline phosphatase, esterase (C4), esterase lipase (C8), leucine arylamidase, valine arylamidase, cystine arylamidase, trypsin, acid phosphatase, naphthol-AS-BI-phosphohydrolase, $\alpha$-glucosidase, $N$-acetyl- $\beta$-glucosaminidase and $\alpha$-mannosidase activities are present. Lipase (C14), $\alpha$-chymotrypsin, $\alpha$ galactosidase, $\beta$-galactosidase, $\beta$-glucosidase, $\beta$-glucuronidase and $\alpha$-fucosidase activities are absent. Starch and Tweens 20 and 80 are hydrolysed but CM-cellulose and casein are not. LRhamnose, $\mathrm{N}$-acetylglucosamine, sucrose, maltose, D-glucose, salicin, melibiose, L-arabitol and L-histidine are assimilated. D-Ribose, inositol, itaconic acid, suberic acid, sodium malonate, sodium acetate, lactic acid, L-alanine, potassium 5-ketogluconate, glycogen, 3-hydroxybenzoic acid, L-serine, D-mannitol, L-fucose, D-sorbitol, propionic acid, capric acid, valeric acid, trisodium citrate, potassium 2-ketogluconate, 3hydroxybutyric acid, 4-hydroxybenzoic acid and L-proline are not assimilated. Acid is produced from sucrose, D-glucose, L-rhamnose, amygdalin, D-xylose, D-galactose, methyl $\alpha$-Dmannopyranoside, methyl $\alpha$-D-glucopyranoside, $N$-acetylglucosamine, arbutin, aesculin, salicin, cellobiose, maltose, lactose, melibiose, sucrose, trehalose, melezitose, raffinose, starch, turanose, D-lyxose and L-arabitol, but not from Dmannitol, inositol, D-sorbitol, glycerol, erythritol, L-xylose, Dadonitol, methyl $\beta$-D-xylopyranoside, D-fructose, D-mannose, dulcitol, inositol, D-mannitol, D-sorbitol, inulin, glycogen, xylitol, gentiobiose, D-tagatose, D-fucose, D-arabitol, potassium 
Table 2. Cellular fatty acid contents of strain $\mathrm{HS} 9^{\top}$ and related members of the genus Sphingobacterium

Strains: 1, S. shayense sp. nov. HS39 ${ }^{\mathrm{T}}$; 2, S. mizutaii ATCC $33299^{\mathrm{T}}$; 3, S. composti KCTC $12578^{\mathrm{T}}$; 4, S. daejeonense KCTC $12579^{\mathrm{T}}$. Values are percentages of total fatty acids; components amounting to $<1.0 \%$ of the total fatty acids in all strains are not shown. tr, Trace $(<1.0 \%)$; - , not detected. All data are from this study.

\begin{tabular}{|c|c|c|c|c|}
\hline Fatty acid & 1 & 2 & 3 & 4 \\
\hline $\mathrm{C}_{14: 0}$ & 1.3 & - & - & - \\
\hline $\mathrm{C}_{16: 0}$ & 3.5 & 1.7 & 1.1 & 2.0 \\
\hline $\mathrm{C}_{18: 0}$ & $\operatorname{tr}$ & 1.0 & 1.0 & 1.0 \\
\hline $\mathrm{C}_{16: 0} 3-\mathrm{OH}$ & 2.4 & $\operatorname{tr}$ & $\operatorname{tr}$ & $\operatorname{tr}$ \\
\hline $\mathrm{C}_{17: 0} 2-\mathrm{OH}$ & 1.1 & $\operatorname{tr}$ & $\operatorname{tr}$ & 3.4 \\
\hline iso- $\mathrm{C}_{15: 0}$ & 28.6 & 38.3 & 38.0 & 32.3 \\
\hline anteiso- $\mathrm{C}_{15: 0}$ & 3.2 & 2.9 & $\operatorname{tr}$ & 7.8 \\
\hline iso- $\mathrm{C}_{15: 0} 3-\mathrm{OH}$ & 2.5 & 1.6 & 2.0 & 1.0 \\
\hline iso- $\mathrm{C}_{17: 0} 3-\mathrm{OH}$ & 13.5 & 18.0 & 17.4 & 15.7 \\
\hline iso- $\mathrm{C}_{15: 1} \mathrm{~F}$ & $\operatorname{tr}$ & 1.8 & 3.0 & 1.6 \\
\hline $\mathrm{C}_{16: 1} \omega 5 c$ & 1.0 & $\operatorname{tr}$ & $\operatorname{tr}$ & - \\
\hline $\mathrm{C}_{18: 1} \omega 5 c$ & $\operatorname{tr}$ & $\operatorname{tr}$ & 1.7 & $\operatorname{tr}$ \\
\hline Summed feature $1^{\star}$ & $\operatorname{tr}$ & 1.3 & 1.9 & $\operatorname{tr}$ \\
\hline Summed feature $3^{*}$ & 37.0 & 20.5 & 19.2 & 24.4 \\
\hline Summed feature $4^{*}$ & $\operatorname{tr}$ & 1.1 & $\operatorname{tr}$ & $\operatorname{tr}$ \\
\hline Summed feature $9^{*}$ & $\operatorname{tr}$ & 5.1 & 9.5 & 2.8 \\
\hline
\end{tabular}

${ }^{*}$ Summed features are groups of two or three fatty acids that cannot be separated by GLC using the MIDI system. Summed feature 1 contained $\mathrm{C}_{13: 0}$ 3-OH and/or iso- $\mathrm{C}_{15: 1} \mathrm{H}$; summed feature 3 contained $\mathrm{C}_{16: 1} \omega 6 c$ and/or $\mathrm{C}_{16: 1} \omega 7 c$; summed feature 4 contained anteiso- $\mathrm{C}_{17: 1} \mathrm{~B}$ and/or iso- $\mathrm{C}_{17: 1} \mathrm{I}$; summed feature 9 contained iso$\mathrm{C}_{17: 1} \omega 9 c$ and/or 10-methyl $\mathrm{C}_{16: 0}$.

gluconate, potassium 2-ketogluconate or potassium 5ketogluconate. Acid is produced weakly from melibiose, Lsorbose, L-fucose, D-arabinose, L-arabinose and D-ribose. Resistant to ampicillin $(10 \mu \mathrm{g})$, neomycin $(30 \mu \mathrm{g})$, streptomycin $(10 \mu \mathrm{g})$, polymyxin B (300 IU), carbenicillin $(100 \mu \mathrm{g})$, gentamicin $(10 \mu \mathrm{g})$, kanamycin $(30 \mu \mathrm{g})$ and penicillin G (10 IU). Sensitive to doxycycline $(30 \mu \mathrm{g})$, lincomycin $(2 \mu \mathrm{g})$, chloramphenicol $(30 \mu \mathrm{g})$, nalidixic acid $(30 \mu \mathrm{g})$, rifampicin $(5 \mu \mathrm{g})$, tetracycline $(30 \mu \mathrm{g})$, vancomycin $(30 \mu \mathrm{g})$ and erythromycin $(15 \mu \mathrm{g})$. The predominant isoprenoid quinone is $\mathrm{MK}-7$. The major fatty acids are iso$\mathrm{C}_{15: 0}$, iso- $\mathrm{C}_{17: 0} 3-\mathrm{OH}$ and summed feature $3\left(\mathrm{C}_{16: 1} \omega 6 c\right.$ and/or $\left.\mathrm{C}_{16: 1} \omega 7 c\right)$. The $\mathrm{G}+\mathrm{C}$ content of the genomic DNA of the type strain is $40.2 \mathrm{~mol} \%$.

The type strain, HS39 ${ }^{\mathrm{T}}$ (=CCTCC AB $209006^{\mathrm{T}}=$ NRRL B$59203^{\mathrm{T}}$ ), was isolated from a soil sample taken from the Xinjiang Uyghur autonomous region, PR China.

\section{Acknowledgements}

We thank Professor Chengxiang Fang, Deputy Director of the China Center for Type Culture Collection (CCTCC), for his technical support. We are also grateful to the USDA Agricultural Research
Service Culture Collection (NRRL). This work was funded by the R \& D Infrastructure and Facility Development Program from the Ministry of Science and Technology of the People's Republic of China (grant no. 2005DKA 21208-9), the Key Laboratory of Oasis Ecology of (Xinjiang University) Ministry of Education (XJDX-200707), the KJZJ Foundation of Xinjiang Uyghur Autonomous Region (201091236) and the Xinjiang Key Laboratory of Extremophiles (XJYS0203-2006-01).

\section{References}

Chun, J., Lee, J.-H., Jung, Y., Kim, M., Kim, S., Kim, B. K. \& Lim, Y. W. (2007). EzTaxon: a web-based tool for the identification of prokaryotes based on $16 \mathrm{~S}$ ribosomal RNA gene sequences. Int J Syst Evol Microbiol 57, 2259-2261.

Collins, M. D., Pirouz, T., Goodfellow, M. \& Minnikin, D. E. (1977). Distribution of menaquinones in actinomycetes and corynebacteria. J Gen Microbiol 100, 221-230.

Felsenstein, J. (1985). Confidence limits on phylogenies: an approach using the bootstrap. Evolution 39, 783-791.

Fitch, W. M. (1971). Toward defining the course of evolution: minimum change for a specific tree topology. Syst Zool 20, 406-416.

Kim, K.-H., Ten, L. N., Liu, Q.-M., Im, W.-T. \& Lee, S.-T. (2006). Sphingobacterium daejeonense sp. nov., isolated from a compost sample. Int J Syst Evol Microbiol 56, 2031-2036.

Kimura, M. (1980). A simple method for estimating evolutionary rates of base substitutions through comparative studies of nucleotide sequences. J Mol Evol 16, 111-120.

Kimura, M. (1983). The Neutral Theory of Molecular Evolution. Cambridge: Cambridge University Press.

Liu, R., Liu, H., Zhang, C. X., Yang, S. Y., Liu, X. H., Zhang, K. Y. \& Lai, R. (2008). Sphingobacterium siyangense sp. nov., isolated from farm soil. Int J Syst Evol Microbiol 58, 1458-1462.

Matsuyama, H., Katoh, H., Ohkushi, T., Satoh, A., Kawahara, K. \& Yumoto, I. (2008). Sphingobacterium kitahiroshimense sp. nov., isolated from soil. Int J Syst Evol Microbiol 58, 1576-1579.

Mehnaz, S., Weselowski, B. \& Lazarovits, G. (2007). Sphingobacterium canadense sp. nov., an isolate from corn roots. Syst Appl Microbiol 30, 519-524.

Mesbah, M., Premachandran, U. \& Whitman, W. B. (1989). Precise measurement of the $\mathrm{G}+\mathrm{C}$ content of deoxyribonucleic acid by highperformance liquid chromatography. Int J Syst Bacteriol 39, 159-167.

Saitou, N. \& Nei, M. (1987). The neighbor-joining method: a new method for reconstructing phylogenetic trees. Mol Biol Evol 4, 406425.

Shivaji, S., Ray, M. K., Rao, N. S., Saisree, L., Jagannadham, M. V., Kumar, G. S., Reddy, G. S. N. \& Bhargava, P. M. (1992). Sphingobacterium antarcticus sp. nov., a psychrotrophic bacterium from the soils of Schirmacher Oasis, Antarctica. Int J Syst Bacteriol 42, 102-106.

Smibert, R. M. \& Krieg, N. R. (1994). Phenotypic characterization. In Methods for General and Molecular Bacteriology, pp. 607-654. Edited by P. Gerhardt, R. G. E. Murray, W. A. Wood \& N. R. Krieg. Washington, DC: American Society for Microbiology.

Steyn, P. L., Segers, P., Vancanneyt, M., Sandra, P., Kersters, K. \& Joubert, J. J. (1998). Classification of heparinolytic bacteria into a new genus, Pedobacter, comprising four species: Pedobacter heparinus comb. nov., Pedobacter piscium comb. nov., Pedobacter africanus sp. nov. and Pedobacter saltans sp. nov. Proposal of the family Sphingobacteriaceae fam. nov. Int J Syst Bacteriol 48, 165-177.

Takeuchi, M. \& Yokota, A. (1992). Proposals of Sphingobacterium faecium sp. nov., Sphingobacterium piscium sp. nov., Sphingobacterium 
heparinum comb. nov., Sphingobacterium thalpophilum comb. nov., and two genospecies of the genus Sphingobacterium and synonymy of Flavobacterium yabuuchiae and Sphingobacterium spiritivorum. J Gen Appl Microbiol 38, 465-482.

Ten, L. N., Liu, Q.-M., Im, W.-T., Aslam, Z. \& Lee, S.-T. (2006). Sphingobacterium composti sp. nov., a novel DNase-producing bacterium isolated from compost. J Microbiol Biotechnol 16, 17281733.

Wei, W., Zhou, Y., Wang, X., Huang, X. \& Lai, R. (2008). Sphingobacterium anhuiense sp. nov., isolated from forest soil. Int $J$ Syst Evol Microbiol 58, 2098-2101.

Wilson, K. (1987). Preparation of genomic DNA from bacteria. In Current Protocols in Molecular Biology, pp. 2.4.1-2.4.5. Edited by F. M. Ausubel, R. Brent, R. E. Kingston, D. D. Moore, J. G. Seidman,
J. A. Smith \& K. Struhl. New York: Green Publishing \& WileyInterscience.

Xie, C. H. \& Yokota, A. (2003). Phylogenetic analysis of Lampropedia hyalina based on the 16S rRNA gene sequence. J Gen Appl Microbiol 49, 345-349.

Yabuuchi, E., Kaneko, T., Yano, I., Moss, C. W. \& Miyoshi, N. (1983). Sphingobacterium gen. nov., Sphingobacterium spiritivorum comb. nov., Sphingobacterium multivorum comb. nov., Sphingobacterium mizutae sp. nov., and Flavobacterium indologenes sp. nov.: glucosenonfermenting Gram-negative rods in CDC groups IIK-2 and IIb. Int J Syst Bacteriol 33, 580-598.

Yoo, S. H., Weon, H. Y., Jang, H. B., Kim, B. Y., Kwon, S. W., Go, S. J. \&

Stackebrandt, E. (2007). Sphingobacterium composti sp. nov., isolated from cotton-waste composts. Int J Syst Evol Microbiol 57, 1590-1593. 